\title{
Callus induction studies in Tridax procumbens $L$.
}

\author{
Minal Wani ${ }^{1 *}$, Snehal Pande ${ }^{1}$ and Nitin More ${ }^{2}$ \\ ${ }^{*}$ Dr. D.Y. Patil Biotechnology and Bioinformatics Institute, Akurdi, Pune, Maharashtra \\ ${ }^{2}$ Department of Biotechnology, New Arts, Commerce and Science College, Wardha \\ minal1412@gmail.com
}

\begin{abstract}
Tridax procumbens is a common weed plant belonging to the family Asteraceae. The leaf juice has antiseptic, insecticidal and parasiticidal properties. The present work is based on developing a protocol for the callus induction in Tridax procumbens from various explants like leaf, internodes and shoot apical buds. The sterilized explants were inoculated in MS media containing various combination of auxins such as 2, 4, dichlorophenoxy acetic acid (2, 4-D) and naphthalene acetic acid (NAA) and cytokinins such as kinetin and 6 benzyl amino purine (BAP). Leaf and apical bud explants showed early and profuse callus induction whereas internodal explants showed comparatively delayed but profuse callus induction. Leaf and apical bud explants showed maximum response in terms of callus by using MS media with the combination 2, 4-D $0.5 \mathrm{mg} / \mathrm{lit}$ and BAP $0.5 \mathrm{mg} / \mathrm{lit}$ which was followed by 2, 4-D 0.5mg/lit and KIN 0.5mg/lit, 2, 4 -D $0.5 \mathrm{mg} / \mathrm{lit}$ and BAP+KIN $0.5 \mathrm{mg} / \mathrm{lit}, \mathrm{NAA} 0.5 \mathrm{mg} / \mathrm{lit}$ and BAP $0.5 \mathrm{mg} / \mathrm{lit}$, NAA $2 \mathrm{mg} / \mathrm{lit}$ and BAP $0.5 \mathrm{mg} / \mathrm{lit}$ respectively. Whereas internodal explants showed maximum callus induction by using a hormonal concentration of $2 \mathrm{mg} / \mathrm{lit} 2,4$, D and $0.5 \mathrm{mg} / \mathrm{lit}$ BAP. In vitro generated callus can be used as a source for the isolation of secondary metabolites from Tridax plant.
\end{abstract}

\section{Introduction}

Tridax procumbens $L$. is a common medicinal herb used by ethno medical practitioners, belonging to the family asteraceae. It is best known as a widespread weed and pest plant. It is commonly known as 'Ghamra' and in English popularly called 'coat buttons' because of the appearance of its flowers. Tridax plant is present throughout India and is employed as indigenous medicine for a variety of ailments. Tridax procumbens has been extensively used in Indian traditional medicine for wound healing, as anticoagulant, antifungal and insect repellent; in diarrhoea and dysentery [1]. Leaf extracts are used to treat infectious skin diseases in folk medicines. It is also dispensed as 'Bhringraj', which is well known aurvedic medicine for liver disorders [12] besides Gastritis and heart burn [5]. Antioxidant properties have also been demonstrated [13] from the plant. Phatak et al investigated hair growth promoting activity of Tridax procumbens [15]. Anti diabetic activity of leaf extract of Tridax plants have been reported [3]. Various phytochemicals present in Tridax procumbens are responsible for the medicinal value of the plant. Explant of an alkaloid producing plant, cultured in vitro, has been found to retain the capacity to synthesis alkaloids identical to that in the intact plant [17]. Callus culture can facilitate optimization of alkaloids production [2] and subsequent isolation [7]. Tissue grown as callus masses can some times yield high amount of secondary metabolites [8]. The present study was undertaken to study the comparative callus induction potential of various plant parts of Tridax by using plant growth hormones.

\begin{abstract}
Materials and Methods
Tridax procumbens plants were collected from the campus of Dr. D.Y. Patil Biotechnology and Bioinformatics Institute, Pune. The plant materials were washed with running tap water for 30 minutes and treated with liquid detergent Teepol followed by washings with autoclaved distilled water thrice. Further sterilization was done under aseptic conditions in a laminar air flow cabinet. The explants, leaf, shoot tip and internodes(stem) were prepared and surface sterilized with Bavistin ( $1 \% \mathrm{w} / \mathrm{v})$ for 3 minutes and with mercuric chloride $(0.1 \% \mathrm{w} / \mathrm{v})$ for 10 minutes followed by washings with sterile distilled water for several times to remove the traces of $\mathrm{HgCl} 2$. The explants were inoculated on MS [9] basal media fortified with $3 \%$ sucrose and supplemented with various combinations and concentrations of auxins 2, 4-D (0.5-2.5 mg/lit) or NAA (0.5-2.5 mg/lit) and cytokinin, kinetin $(0.5 \mathrm{mg} / \mathrm{l})$ or $\mathrm{BA}$ and $(0.5 \mathrm{mg} / \mathrm{l}) . \mathrm{pH}$ of the media was adjusted at 5.8 by using $0.1 \mathrm{~N} \mathrm{NaOH}$ and $0.1 \mathrm{~N} \mathrm{HCl}$ before gelling the medium with $0.8 \%$ agar- agar type (Himedia).

The cultures were incubated at $25 \pm 1{ }^{\circ} \mathrm{C}$ with a photoperiod of $16 \mathrm{~h}$ at 3000 lux light intensity of cool white fluorescent light. All the experiments were repeated twice with 10 cultures per treatment. Data were taken after 4-6 weeks by visual observation of the culture.
\end{abstract}

\section{Results and discussion}

All the combinations of 2, 4 D, NAA with BAP and kinetin produced callus with variable response (Table 1). There were significant differences in frequency and degree of callusing. Early callus induction was observed in leaf and shoot apex explants whereas in internodes showed delayed 
callusing. The observations for leaf and shoot apex were taken after 6 weeks whereas for internodes the results were obtained after 8 weeks. Growth of the callus increased significantly with the incubation period from 4-6 weeks in explants leaf and shoot apex. Internodal explants initiated callus after about 20 days of incubation but the growth was continuous up to 8th week of incubation. After the initiation green friable callus gradually covered the entire surface of the explants. Profuse callus was formed on MS medium supplemented with 2, 4 D $0.5 \mathrm{mg} / \mathrm{l}$ and BAP $0.5 \mathrm{mg} / \mathrm{l}$ by leaf, shoot apex and intermodal explants. Similar results were also reported for callus induction in Aconitum heterophyllum [11]. Studies on leaf callus induction in Bupleurum showed that lower concentration of $2,4, D$ is more beneficial and increase in 2, 4, D concentrations did not improved callus induction[16]. Inclusion of an auxin and cytokinin will be necessary for callus growth. The best callus induction was showed by internodes when hormones 2,4 D 2mg/l and BAP $0.5 \mathrm{mg} / \mathrm{l}$ were used. Shoot apex also exhibited good response in terms of callus by using various concentrations of $\mathrm{NAA}+0.5 \mathrm{mg} / \mathrm{l} \mathrm{BAP}$ and 2, $4 \mathrm{D} 0.5 \mathrm{mg} / \mathrm{l}+$ kinetin $0.5 \mathrm{mg} / \mathrm{l}$. Highest percentage of callus induction from shoot tips of Cassia obtusifolia L. was reported by using a combination of $2,4 \mathrm{D}$ and kinetin[6]. Degree of callus induction was comparatively low when hormones NAA and kinetin was used. This is in contrast with the result of callus induction studies in Ipomea [10]. It was observed that 2, $4 \mathrm{D}$ was the best source of auxin for callus induction in Tridax explants in combination with BAP or Kinetin which was followed by auxin NAA along with BAP. Profuse callus induction on MS medium supplemented with NAA $2.0 \mathrm{mg} / \mathrm{l}$ + BA $0.5 \mathrm{mg} / \mathrm{l}$ has been reported in Rauwolfia serpentina [14]. The hormones NAA and BAP were reported as the best hormones for callus induction by some researchers [4]. From the current studies it is observed that of the various explants used for callus induction the best callusing was obtained from shoot apex which was followed by leaf and intermodal explants respectively. The response of the shoot apex might be due to the presence of higher amount of meristematic tissues in the explants. Effective in vitro callus mass production can be beneficial for high yield of secondary metabolites and optimization of alkaloid production. In vitro generation of callus can encourage in vitro mass production of bioactive compounds of health benefits from Tridax procumbens plant.

\section{Acknowledgement}

Authors wish to thank Dr. Vidya Kothekar, Director, Dr. D.Y. Patil Biotechnology and Bioinformatics Institute, for providing the laboratory facilities. The assistance of students
Suchi Desai and Ritu Singh are duly acknowledged.

\section{References}

[1] Ali M., Ravinder E. and Ramachandran R. (2001) Fitoterapia, 72, 313-315.

[2] Anitha S. and Kumari B.D.R. (2006) Afr. J. Biotechnology, 5, 659-661.

[3] Bhagwat D. A., Killedar S. G. and Adnaik R. S. (2008) Int. J. Green Pharm., 2, 126128.

[4] Biswas A., Roy M., Miah M. A. B. and Bhadra S. K. (2007) Plant Tissue Cult. Biotechnol., 17, 59-64.

[5] Glover P. E., Stewart J., Gwynne Masai M. D. (1966) East Afr. Agri.Forest J., 32, 200-207.

[6] Hasan M.F., Das R., Rahman M.S., Rashid M.H., Hossain M.S. and Rahman M. (2008) Int. J. Sustain. Crop Prod., 3(6), 6-10.

[7] Kirillova, N.V., Smirnova M.G. and Komov V. P. (2001) Prikl. Biokhim. Mikrobiol., 37, 181-185.

[8] Maheshwari P., Songara B., Kumar S., Jain P., Srivastava K. and Kumar A. (2007) Biotechnol. J., 2, 1026-1032.

[9] Murashige T. and Skoog F. (1962) Plant Physiol., 15, 473-497.

[10] Nagendra Prasad K., Shiva Prasad M., Shivamurthy G.R. and Aradya S.M. (2006) Indian J. of Bioteh., 5,107-111.

[11] Neelofar Jabeen, Shawl A.S., Dar G.H., Arif Jan and Phalisteen Sultan (2006) Biotechnology, 5(3), 287-291.

[12] Pathak A.K., Saraf S. and Dixit V.K. (1991) Fitoterapia, 62, 307-313.

[13] Ravikumar V., Kanchi Subramanian, Shivashangari and Devaki T. (2005) Molecular and Cellular Biochemistry, 269, 131-136.

[14] Salma U., Rahman M. S. M., Islam S., Haque N., Jubair T. A., Haque A. K. M. F. and Mukti I. J. (2008) Pak. J. Biol. Sci., 11 (12), 1638-1641.

[15] Saraf S, A.K. Pathak and V.K. Dixit. (1991) Fitoterapia. 62: 495-498.

[16] Uei-Chern Chen, Fu-Shin Chueh, Chi-Ni Hsia, Mau-Shing Yeh and Hsin-Sheng Tsay. (2005) Crop, Environment \& Bioinformatics, 2, 39-49.

[17] Yoshimatsu K. and Shimomura. (1991) Plant Cell Rep., 9, 567-570. 


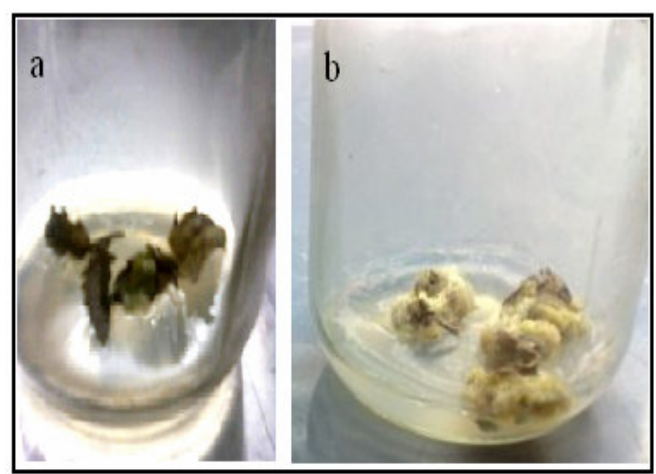

Fig. 1- Shoot apex a. Explant b. Callus

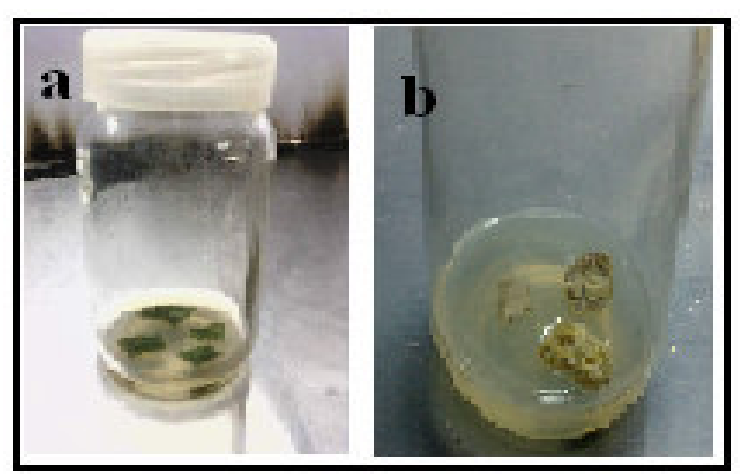

Fig. 2- Leaf a. Explant b. Callus

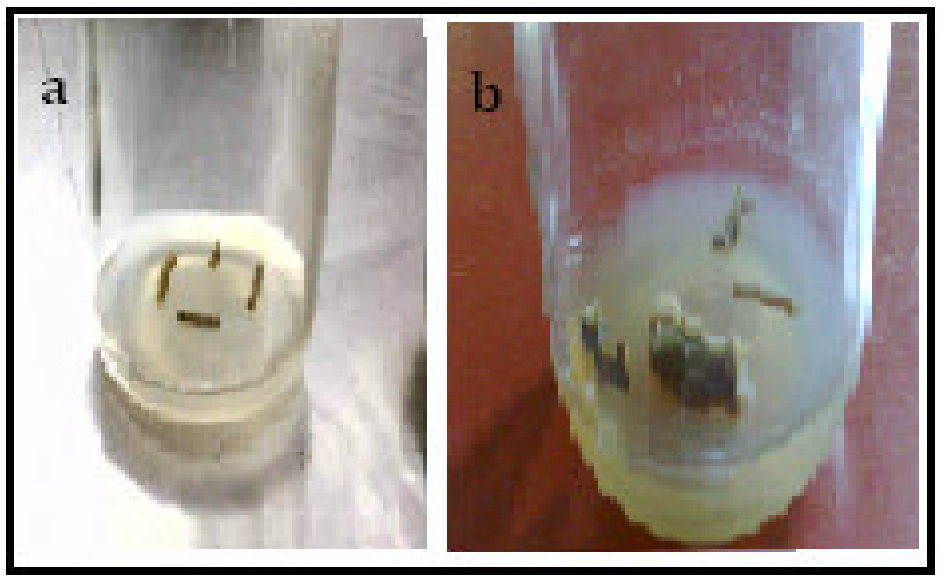

Fig. 3- Internode a. Explant b. Callus 
Table I- Effect of different concentrations and combinations of plant growth hormones in MS medium for callus induction from various explants of Tridax procumbens.

Degree of callusing: + poor callus, ++medium callus, +++ good callus, ++++ profuse callus Nature of callus- friable and greenish yellow in color

\begin{tabular}{|c|c|c|c|c|c|}
\hline Explant & \multicolumn{5}{|c|}{$2,4 \mathrm{D}+\mathrm{BAP} \mathrm{mg} / \mathrm{l}$} \\
\hline & $0.5+0.5$ & $1.0+0.5$ & $1.5+0.5$ & $2.0+0.5$ & $2.5+0.5$ \\
\hline Leaf & +++ & ++ & + & ++ & ++ \\
\hline Shoot apex & ++++ & ++ & ++ & ++ & +++ \\
\hline \multirow[t]{2}{*}{ Internodes } & +++ & ++ & ++ & +++ & ++ \\
\hline & \multicolumn{5}{|c|}{$2,4 \mathrm{D}+$ Kinetin $\mathrm{mg} / \mathrm{l}$} \\
\hline Leaf & +++ & ++ & ++ & ++ & ++ \\
\hline Shoot apex & ++++ & ++ & ++ & ++ & +++ \\
\hline \multirow[t]{2}{*}{ Internodes } & ++ & + & ++ & + & ++ \\
\hline & \multicolumn{5}{|c|}{$\mathrm{NAA}+\mathrm{BAP} \mathrm{mg} / \mathrm{l}$} \\
\hline Leaf & ++ & ++ & + & ++ & + \\
\hline Shoot apex & ++++ & ++ & +++ & +++ & ++ \\
\hline \multirow[t]{2}{*}{ Internodes } & +++ & + & ++ & ++ & + \\
\hline & \multicolumn{5}{|c|}{ NAA + Kinetin } \\
\hline Leaf & + & + & + & ++ & ++ \\
\hline Shoot apex & + & + & ++ & ++ & ++ \\
\hline Internodes & ++ & + & ++ & ++ & + \\
\hline
\end{tabular}

(The experiments were repeated twice, each experiments consisting of 10 replicates.) 